\title{
Representing motion in a static image 静止画像における動きの表現
}

\author{
講演者 James E. Cutting \\ Cornell University \\ 司会三浦佳世（九州大学）
}

\section{講演者の紹介}

Cutting 教授は、1947 年にワシントン D.C.で生まれ、1969 年にノースカロライナ大学で修士号を、 1973 年にエール大学で PhD をとった後、エール大学、ウエスレヤン大学を経て、1980 年からコーネル大 学に移り現在、教授として教鞭をとっている。100 を越える論文と 2 冊の本を執筆する傍ら、1989-1993 年には JEP:HPP、2003 年からは Psychological Scienceの編集長としても活躍しており、Psychonomic Bulletin \& Review や Cognition、Cognitive Psychology などの編集にも携わってきた。運動視や奥行知 覚、レイアウト知覚、あるいは wayfinding などの基礎的な知覚研究を行うとともに、芸術や映画の研究 でも知られ、1993 年には西洋美術における奥行表現に関する研究で John Simon Guggenheim Memorial Fellowship を受賞している。なお、大学に勤める前には、Atari Sunnyvale Research Laboratory の研究 員や、プロのダンサーでもあったなど、多彩な経歴をもった才人でもある。詳しくは下記を参照。 http://www2.psych.cornell.edu/cutting/

\section{講演の内容}

Representing motion in a picture is a challenged to artists, scientists, graphic artists, and all other image makes. Moreover, it present a problem that will not go away with electronic and digital media, because of then pedagogical purpose of the representation of motion is more important that the motion itself. All satisfactory solutions evoke motion - for example, dynamic balance (or broken symmetry), stroboscopic sequences, affine shear (or forward lean), and photographic blur - but the also typically sacrifice the accuracy of the motion represented, a solution often unsuitable for science. Vector representations superimposed on static images allow for accuracy but are not applicable to all situations. Workable solutions are almost certainly case specific and subject to continual evolution through exploration by imagemakers.

\section{主な著書・論文}

Cutting, J. E. (1986). Perception with an eye for motion. Cambridge, MA: MIT Press.

Cutting, J.E. (1987). Rigidity in cinema seen from the front row, side aisle. Journal of Experimental Psychology: Human Perception and Performance, 13, 323-334.

Cutting, J.E. (1988). Affine distortions of pictorial space: Some predictions for Goldstein (1987) that La Gournerie (1859) might have made. Journal of Experimental Psychology: Human Perception and Performance, 14, 305-311.

Cutting, J.E \& Vishton, P.M. (1995). Perceiving layout and knowing distances: The interaction, relative potency, and contextual use of different information about depth. In W. Epstein \& S. Rogers (Eds.) Perception of space and motion (pp. 69-117). San Diego, CA: Academic Press.

Cutting, J.E. \& Massironi, M. (1998). Pictures and their special status in cognitive inquiry. In J. Hochberg (ed.) Perception and cognition at the end of the century (pp. 137-168) San Diego, CA: Academic Press.

Cutting, J.E. (2000). Images, imagination, and movement: Pictorial representations and their development in the work of James Gibson. Perception, 29, 635-648.

Cutting, J.E. (2002). Representing motion in a static image: Constraints and parallels in art, science, and popular culture. Perception, 31, 1165-1194.

Cutting, J.E. (2003). Gustave Caillebotte, French Impressionism, and mere exposure. Psychonomic Bulletin \& Review, 10, 319-343.

Cutting, J.E. (2005). Perceiving scenes in film and in the world. In J.D. Anderson \& B.F. Anderson (Eds.) Moving image theory: Ecological consideration (pp. 9-27). Carbondale, IL: University of SouthernIllinois Press.

Cutting, J.E. (2006). Impressionism and its canon. Lanham, MD: University Press of America. 